\title{
Occasional Surveys
}

\section{Tuberculosis: who should prescribe?}

\author{
A G WARDMAN，S E WILLIAMS，P G D CURZON，R L PAGE， N J COOKE
}

The efficacy of modern antituberculosis chemotherapy is well established. The relapse rate of roughly $4 \% \%^{12}$ is mainly due to patients' non-compliance ${ }^{2} 3$ and, in a few cases, to drug resistance. A potentially avoidable cause of failure is the prescription of inappropriate chemotherapy.

Patients with tuberculosis present to several disciplines, nonrespiratory physicians tending to instigate and supervise chemotherapy. In North America, where an attempt has been made to encourage treatment of tuberculosis by general physicians, one study ${ }^{4}$ suggested an incidence of prescription errors of over $50 \%$ by recently trained non-respiratory physicians, possibly because of inadequacies in medical school curricula. Crofton has recently drawn attention to the same problem in Britain. ${ }^{5}$

The aim of the present study was to identify the therapeutic errors and their consequences in a teaching hospital practice.

\section{Methods}

Two respiratory physicians (NJC and RLP) working at the Leeds teaching hospitals reviewed all cases of tuberculosis where treatment error had occurred coming under their care over a two-year period. We wanted to ascertain the type and source of error rather than its incidence, and therefore a full retrospective survey of all cases of tuberculosis was not undertaken.

We examined the hospital records of those patients where treatment error had occurred and recorded the department instigating treatment, site of disease, type of error in terms of drug dosage, timing of administration and duration, and consequence of error (table).

\section{Leeds Chest Clinic, Leeds LS1 6PH}

A G WARDMAN, MB, MRCP, medical registrar

$S$ E WILLIAMS, MD, MRCP, senior medical registrar

P G D CURZON, MB, MRCP, medical registrar

R L PAGE, DM, MRCP, consultant chest physician

N J COOKE, BSC, MRCP, consultant chest physician

\section{Results}

THE PATIENTS

Ten case records were studied. Six patients had proved tuberculosis, three had probable but bacteriologically unconfirmed tuberculosis, and one (case 9) had an undiagnosed pleural effusion with little evidence of tuberculosis. All 10 patients had been started on inappropriate chemotherapy before referral. In seven cases referral occurred within one month of starting treatment, in one the delay was six weeks, and in two no direct referral was made. Short case reports of these last three patients are given below.

Case 1-A 70-year-old Caucasian woman presented in 1960 with tuberculous disease of the hip. Her treatment at that time is unknown. In December 1971 she developed back pain and spinal tuberculosis was confirmed. She was treated with bed rest, streptomycin $1 \mathrm{~g}$ once a day, and isoniazid $150 \mathrm{mg}$ and para-aminosalicylic acid $6 \mathrm{~g}$ (her weight was $65 \mathrm{~kg}$ ), both twice daily. When discharged three months later she was taking no drugs, but she required readmission one week later with persisting back pain. Bed rest was reinstituted, and for five months she took, twice a day, streptomycin $0.5 \mathrm{~g}$ and ethambutol $300 \mathrm{mg}$. She was again discharged taking no drugs. In March 1981 she became gravely ill with renal tuberculosis, from which she eventually died.

Case 2-A 43-year-old Asian woman presented in October 1975 with a fever for which no cause was found. One month later she was readmitted with continuing fever and hip pain; histological examination confirmed tuberculous disease of the hip. In March 1976 she started taking streptomycin, $1 \mathrm{~g}$ once a day, and isoniazid $150 \mathrm{mg}$ and para-aminosalicylic acid $6 \mathrm{~g}$ (weight $60 \mathrm{~kg}$ ) three times a day. After five weeks this regimen was changed to streptomycin $1 \mathrm{~g}$ and rifampicin $450 \mathrm{mg}$, both once a day. Two weeks later the streptomycin was stopped, and she continued to take rifampicin at the same dose for 21 months. She was not closely supervised over this period and eventually presented in 1981 with cryptic miliary tuberculosis.

Case 3-A 73-year-old Caucasian woman presented in June 1978 with a tuberculous breast abscess, which was treated twice a day with rifampicin $450 \mathrm{mg}$ and isoniazid $300 \mathrm{mg}$ and once a day with ethambutol $1000 \mathrm{mg}$ before breakfast (weight $60 \mathrm{~kg}$ ). Six weeks later she developed an unsteady gait with signs of a severe peripheral neuropathy. Despite modification of her treatment some of the neurological deficit persists. 
THE ERRORS

We examined 13 courses of treatment (table). In 10 of these a dosage error occurred in one or more of the drugs used, and in 11 the drugs were given at inappropriate times or no time was specified. In only one course were drugs prescribed at the correct dose and time, but this course was inadequate in duration (case 1, first course)

Isoniazid was used in 10 of the courses. The recommended daily dose is $200-300 \mathrm{mg}^{6}{ }^{6}$ In two courses an inadequate dose $(150 \mathrm{mg}$ ) was prescribed and in two the daily doses were excessive $(450 \mathrm{mg}$ and $600 \mathrm{mg}$ ). It should not be given in divided doses (unless used with para-aminosalicylic acid) as there is evidence that a high peak concentration is more important than a continuous inhibitory concentration. ${ }^{7}$ In five of the 10 courses this drug was given inappropriately in divided doses and in one the timing was unspecified.

Rifampicin was used in nine treatment courses. The recommended daily dose is $450 \mathrm{mg}$ below $50 \mathrm{~kg}$ body weight and $600 \mathrm{mg}$ above this weight (or $8-12 \mathrm{mg} / \mathrm{kg}$ body weight). ${ }^{6}{ }^{8}{ }^{9}$ In six courses the daily dose was low (300-450 mg) and in one excessively high (900 mg). Absorption and therefore peak serum concentrations are reduced when the drug is taken with food. Though the clinical importance of this has been questioned, ${ }^{10}$ the recommendation is still that the drug should be given as a single daily dose half an hour before breakfast. ${ }^{6} 89$ The timing of administration was incorrect in all nine courses. Either the drug was given in divided doses (3) or the timing was unspecified (4), or the drug was given with breakfast (2).

Ethambutol was prescribed in eight treatment courses. The recommended single daily dose is $15-25 \mathrm{mg} / \mathrm{kg}$ body weight, providing peak serum concentrations of $3-5 \mu \mathrm{g} / \mathrm{ml}^{6}{ }^{6}$ Such single-dose concentrations are of proved efficacy when used with isoniazid, but lower doses are less effective. ${ }^{1112}$ Ocular toxicity appears to be dose related, being negligible with $15 \mathrm{mg} / \mathrm{kg}$ and roughly $3 \%$ with $25 \mathrm{mg} / \mathrm{kg} \cdot{ }^{13} \mathrm{In}$ our patients the dose was incorrect in two courses, one of $13.5 \mathrm{mg} / \mathrm{kg}$ and one of $30 \mathrm{mg} / \mathrm{kg}$. Dividing the daily dose results in lower peak concentrations. ${ }^{14}$ In four courses the drug was given in divided doses.

Streptomycin was given in the correct dose in four treatment courses. In one the drug was given in divided daily doses. This is unnecessary in a drug with such a long half life.

\section{Discussion}

Several errors were identified in this study. Drugs were given in inadequate doses or incorrectly in divided doses. This can lead to inadequate blood concentrations with the possibility that resistant organisms would develop. Drugs were also given in excessive doses, with the possibility of toxic side effects. Finally, in two patients the duration of treatment was too short.

The duration of treatment required depends on the drugs used. Eighteen months' treatment with isoniazid and para-aminosalicylic acid with initial streptomycin is of proved efficacy in pulmonary $^{2}$ and spinal ${ }^{15}$ tuberculosis. Reduction of this regimen to 12 months is associated with an increased relapse rate in pulmonary tuberculosis. ${ }^{16}$ More recently, regimens using rifampicin in triple treatment (with isoniazid and initial ethambutol) have been successful against pulmonary tuberculosis when given for only nine months. ${ }^{17} \mathrm{~A}$ reduction to six months is associated with a higher and unacceptable relapse rate. ${ }^{18}$ There is some evidence that other types of tuberculosis will respond in a similar way to rifampicin-containing regimens, ${ }^{19}$ though confirmation is awaited.

The case reports illustrate these errors in dosage and duration of treatment. In the first case triple chemotherapy for three months was followed by too low a dose of ethambutol $(600 \mathrm{mg}$ instead of $1000 \mathrm{mg}$ ) combined with streptomycin, both drugs being given incorrectly in divided doses. The total duration of treatment was only eight months: in regimens without rifampicin, as mentioned above, 18 months' treatment should probably be advised.

In the second case initial treatment was given for only five weeks, followed by two drugs for two weeks and then one drug for 21 months. Using a single antituberculosis drug is a classic error because of the possibility that resistance will develop. Rifampicin was prescribed in too low a dose $(450 \mathrm{mg}$ instead of $600 \mathrm{mg}$ ), which was given at an unspecified time, and the treatment was poorly supervised. The dose of isoniazid was unnecessarily high (450 mg instead of $300 \mathrm{mg}$ ) and no pyridoxine was given. This is necessary when higher doses of isoniazid are used to prevent peripheral neuropathy. ${ }^{20}$

The third case illustrates the toxicity of isoniazid when used in large doses (600 $\mathrm{mg}$ instead of $300 \mathrm{mg}$ ), especially when no pyridoxine is given. The ensuing neuropathy was only partially reversible. In this case rifampicin was also given in excess (900 $\mathrm{mg}$ instead of $600 \mathrm{mg}$ ).

Of the 10 patients in whom errors in treatment were identified, only three suffered consequences. These errors were, however, all avoidable. Two cases were treatment failures; the remaining patients were seen by a respiratory physician while undergoing treatment and the errors were corrected. Had this not been so more treatment failures would probably have occurred.

With modern chemotherapy treatment of tuberculosis is highly successful when the drugs are given in therapeutic doses for a long enough period. Failure to give appropriate treatment may be disastrous. Infrequent opportunity to treat tuberculosis is likely to correlate with increased errors in prescription, and therefore we consider that there is a strong argument for all cases of tuberculosis to be referred to a respiratory physician for chemotherapeutic management from the outset.

\section{References}

1 Springett VH. Ten-year results during the introduction of chemotherapy for tuberculosis. Tubercle 1971;52:73-87.

2 Pearce SJ, Horne NW. Follow-up of patients with pulmonary tuberculosis adequately treated by chemotherapy: is this really necessary? Lancet $1974 ;$ ii :641-3.

${ }^{3}$ Hayden SP, Springett VH. An assessment of the place of follow-up in pulmonary tuberculosis. BrF Dis Chest 1978;72:217-21.

' Byrd RB, Horne BR, Solomon DA, Griggs GA, Wilder NJ. Treatment of tuberculosis by the nonpulmonary physician. Ann Intern Med $1977 ; 86$ : 799-802.

5 Crofton J. Treatment of tuberculosis. Br Med F 1979;i :52.

${ }^{6}$ Ross JD, Horne NW. Modern drug treatment in tuberculosis. 5th ed. London: The Chest, Heart and Stroke Association, 1976.

Details of 10 cases where treatment error had occurred

\begin{tabular}{|c|c|c|c|c|c|c|c|c|c|c|c|}
\hline \multirow{3}{*}{$\begin{array}{c}\begin{array}{c}\text { Case } \\
\text { No }\end{array} \\
1\end{array}$} & \multirow{3}{*}{$\frac{\text { Race }}{\text { Caucasian }}$} & \multirow{3}{*}{$\frac{\begin{array}{c}\text { Age } \\
\text { (years) }\end{array}}{70}$} & \multirow{3}{*}{$\begin{array}{r}\begin{array}{r}\text { Site of } \\
\text { disease }\end{array} \\
\text { Spine }\end{array}$} & \multirow{3}{*}{$\begin{array}{c}\begin{array}{c}\text { Referral } \\
\text { source }\end{array} \\
\text { Orthopaedics }\end{array}$} & \multirow{2}{*}{\multicolumn{3}{|c|}{$\begin{array}{l}\text { Drugs } \\
\text { used }\end{array}$}} & \multicolumn{2}{|c|}{ Error present } & \multirow{3}{*}{$\begin{array}{c}\begin{array}{c}\text { Duration } \\
\text { of error } \\
\text { (days) }\end{array} \\
\text { Uncorrected }\end{array}$} & \multirow{2}{*}{$\begin{array}{l}\text { Consequence } \\
\text { of error }\end{array}$} \\
\hline & & & & & & & & Dose & Timing & & \\
\hline & & & & & $\begin{aligned} & \text { i) } S \\
& \text { ii) } S \\
& \text { i }\end{aligned}$ & $\begin{array}{l}\text { PAS } \\
\text { E } \\
\text { PAS }\end{array}$ & $\begin{array}{l}\mathrm{H} \\
\mathrm{H}\end{array}$ & $\begin{array}{l}\text { No } \\
\text { Yes } \\
\text { Yes }\end{array}$ & $\begin{array}{l}\text { No } \\
\text { Yes } \\
\text { No }\end{array}$ & & $\begin{array}{l}\text { Renal tuberculosis } \\
8 \text { years later } \\
\text { Cryptic miliary }\end{array}$ \\
\hline 2 & Asian & 43 & Hip & Orthopaedics & ii) $\mathrm{S}$ & $\stackrel{R}{R}$ & & Yes & Yes & Uncorrected & tuberculosis \\
\hline $\begin{array}{r}3 \\
4 \\
5 \\
6 \\
7 \\
8 \\
9 \\
10\end{array}$ & $\begin{array}{l}\text { Caucasian } \\
\text { Caucasian } \\
\text { Caucasian } \\
\text { Caucasian } \\
\text { Asian } \\
\text { Caucasian } \\
\text { Caucasian } \\
\text { Asian }\end{array}$ & $\begin{array}{l}73 \\
46 \\
75 \\
47 \\
55 \\
62 \\
73 \\
44\end{array}$ & $\begin{array}{l}\text { Breast } \\
\text { Lung and kidney } \\
\text { Lung } \\
\text { Lung } \\
\text { Spine } \\
\text { Lung } \\
\text { Pleura } \\
\text { Pleura }\end{array}$ & $\begin{array}{l}\text { General surgery } \\
\text { Thoracic surgery } \\
\text { General medical } \\
\text { Thoracic surgery } \\
\text { Orthopaedics } \\
\text { General medical } \\
\text { General medical } \\
\text { General medical }\end{array}$ & iii) $\begin{array}{r}\mathbf{R} \\
\mathbf{R} \\
\mathbf{R} \\
\mathbf{R} \\
\mathbf{R} \\
\mathbf{R} \\
\mathbf{R}\end{array}$ & $\begin{array}{l}\mathrm{R} \\
\mathrm{E} \\
\mathrm{E} \\
\mathrm{E} \\
\mathrm{E} \\
\mathrm{E} \\
\mathrm{E} \\
\mathrm{E}\end{array}$ & $\begin{array}{l}\mathrm{H} \\
\mathrm{H} \\
\mathrm{H} \\
\mathrm{H} \\
\mathrm{H} \\
\mathrm{H} \\
\mathrm{H} \\
\mathrm{H} \\
\mathrm{H}\end{array}$ & $\begin{array}{l}\text { Yes } \\
\text { Yes } \\
\text { Yes } \\
\text { Yes } \\
\text { No } \\
\text { Yes } \\
\text { Yes } \\
\text { Yes } \\
\text { No }\end{array}$ & $\begin{array}{l}\text { Yes } \\
\text { Yes } \\
\text { Yes } \\
\text { Yes } \\
\text { Yes } \\
\text { Yes } \\
\text { Yes } \\
\text { Yes } \\
\text { Yes }\end{array}$ & $\begin{array}{r}42 \\
30 \\
21 \\
14 \\
8 \\
6 \\
4 \\
1\end{array}$ & $\begin{array}{l}\text { 5 years later } \\
\text { Peripheral neuropathy } \\
\text { Treatment prolonged }\end{array}$ \\
\hline
\end{tabular}

$\mathrm{S}=$ Streptomycin. $\mathrm{H}=$ Isoniazid. $\mathrm{E}=$ Ethambutol. $\mathrm{R}=$ Rifampicin. PAS = Para-aminosalicylic acid. 
' Gangadharam PRJ, Devadatta S, Fox W, Narayanan Nair C, Selkon JB. Rate of inactivation of isoniazid in South Indian patients with pulmonary tuberculosis. Bull WHO $1961 ; 25: 793-806$.

${ }^{8}$ Data sheet. Rifadin. Lepetit Pharmaceuticals Ltd.

${ }^{9}$ Data sheet. Rimactane. Ciba Laboratories.

10 Siegler DI, Bryant M, Burley DM, Citron KM, Standen SM. Effect of meals on rifampicin absorption. Lancet 1974 ;ii:197-8.

${ }^{11}$ Donomae I, Yamamoto K. Clinical evaluation of ethambutol in pulmonary tuberculosis. Ann NY Acad Sci 1966;135:849-81.

${ }^{12}$ Doster B, Murray FJ, Newman R, Woolpert SF. Ethambutol in the initial treatment of pulmonary tuberculosis. Am Rev Respir Dis 1973;107: 177-90.

${ }^{13}$ Citron KM. Ethambutol: a review with special reference to ocular toxicity. Tubercle $1969 ; \mathbf{5 0}$ suppl:32.

14 Place VA, Thomas JP. Clinical pharmacology of ethambutol. Am Rev Respir Dis 1963;87:901-4.
15 Medical Research Council working party on tuberculosis of the spine. Sixth report. F Bone foint Surg 1978;60B:163-77.

16 Medical Research Council Tuberculosis Chemotherapy Trials Committee. Report to the MRC. Tubercle $1962 ; 43: 201-67$.

17 British Thoracic and Tuberculosis Association. Short course chemotherapy in pulmonary tuberculosis. Lancet 1975; i:119-24.

18 British Thoracic Association. Short course chemotherapy in pulmonary tuberculosis. Lancet $1980 ; 1: 1182-3$.

19 Gow JG. Genitourinary tuberculosis, a seven year review. $\mathrm{Br} \mathcal{F}$ Urol $1979 ; 51: 239-44$

${ }^{20}$ Devadatta S, Gangadharam PRJ, Andrews RJ, et al. Peripheral neuritis due to isoniazid. Bull WHO $1960 ; 23: 587-98$.

\title{
Survey of pulmonary tuberculosis in south and west Wales (1976-8)
}

\author{
R D H MONIE, A M HUNTER, KAREN ROCCHICCIOLI, JANINE WHITE, I A CAMPBELL, \\ G S KILPATRICK
}

\begin{abstract}
In routine clinical practice $20 \%$ of patients with pulmonary tuberculosis were treated with the regimen recommended by the British Thoracic Association after the British trial of short-course chemotherapy. Despite the use of several regimens that could be considered inadequate, no patient from the survey within south and west Wales appears to have relapsed yet. Deaths from pulmonary tuberculosis continue at the same rate as 10 years ago. Patient default remains a difficult problem even with modern, less toxic, short-course regimens.
\end{abstract}

\section{Introduction}

After the British Thoracic Association's short course chemotherapy trial, it was recommended that treatment with rifampicin (R) plus isoniazid $(\mathrm{H})$ for nine months, together with ethambutol (E) for the initial two months, should be accepted as standard chemotherapy for pulmonary tuberculosis in the United Kingdom. ${ }^{1}$ This regimen has the advantage of using less toxic drugs and reducing the period of chemotherapy required from 18 months to nine, thereby theoretically increasing the likelihood of good compliance.

To assess how widely the recommended regimen has been adopted, and with what results, we have carried out a retrospective survey of the management of cases of tuberculosis in parts of Wales.

Welsh National School of Medicine, Llandough Hospital, Penarth, S Glamorgan CF6 1 XX

$\mathrm{R}$ D H MONIE, MB, MRCP, lecturer in chest diseases

G S KILPATRICK, MD, FRCP, David Davies professor of tuberculosis and chest diseases

Department of Thoracic Medicine, Llandough Hospital, Penarth, S Glamorgan CF6 1XX

A M HUNTER, MB, MRCP, senior registrar

KAREN ROCCHICCIOLI, MB, MRCP, registrar (present appointment: research registrar, Wythenshawe Hospital, Manchester)

JANINE WHITE, MB, MRCP, registrar (present appointment: research fellow, Guy's Hospital, London)

I A CAMPBELL, MD, MRCP, consultant chest physician

\section{Methods}

The survey covered three years from 1 January 1976 to 31 December 1978 and included the five counties of south and west Wales, the population of which is just over 2 million. ${ }^{2}$

Cases of tuberculosis were traced from three sources: (1) the Hospital Activity Analysis forms, on which the diagnosis is recorded at the time of the patient's discharge from hospital; (2) the Mycobacterium Reference Unit of the Public Health Laboratory Service in Cardiff; and (3) the notification lists of patients with tuberculosis from the medical officers for environmental health.

A complete list of patients who had tuberculosis in the three-year period of the survey was made for each county, and the list circulated to the medical records officers of each hospital and chest clinic within that county. The hospital or chest clinic was visited, and the notes of each patient on the list were reviewed.

Information taken from the notes included: $(a)$ age and sex, $(b)$ the basis for the diagnosis of tuberculosis, $(c)$ the regimen prescribed and the duration of the treatment, $(d)$ how well the patient complied with treatment (poor drug compliance was registered if the physician supervising treatment recorded it in the patient's notes or if the patient failed to attend clinic on two or more occasions without good reason), $(e)$ number of deaths, $(f)$ side effects of drugs, and $(g)$ number of relapses.

\section{Results}

We reviewed the case notes of 753 patients.

Age and sex-Table I shows the number of cases of tuberculosis within each age group and the incidence of tuberculosis related to the age of the population: $72 \%$ of the patients were male, and $6.4 \%$ of all patients were non-Caucasian.

Basis for diagnosis-Mycobacterium tuberculosis was cultured from the sputum in 588 patients $(78 \%)$, while $165(22 \%)$ were culture

TABLE I-Incidence of tuberculosis in South and West Wales

\begin{tabular}{|c|c|c|c|c|c|}
\hline \multirow{2}{*}{$\begin{array}{c}\text { Age } \\
\text { (years) }\end{array}$} & \multicolumn{3}{|c|}{ No of cases } & \multirow{2}{*}{$\begin{array}{l}\text { Percentage of } \\
\text { whole group }\end{array}$} & \multirow{2}{*}{$\begin{array}{l}\text { No of cases per } \\
100000 \text { of } \\
\text { population a year }\end{array}$} \\
\hline & Male & Female & Total & & \\
\hline $\begin{array}{c}0-4 \\
5-14 \\
15-44 \\
45-64 \\
65-74 \\
\geqslant 75\end{array}$ & $\begin{array}{r}12 \\
20 \\
143 \\
207 \\
102 \\
58\end{array}$ & $\begin{array}{r}6 \\
15 \\
80 \\
74 \\
16 \\
20\end{array}$ & $\begin{array}{r}18 \\
35 \\
223 \\
281 \\
118 \\
78\end{array}$ & $\begin{array}{r}2.4 \\
4.6 \\
29.6 \\
37.5 \\
15.7 \\
10.4\end{array}$ & $\begin{array}{r}4.9 \\
1.2 \\
8.9 \\
19.4 \\
20.4 \\
23.8\end{array}$ \\
\hline
\end{tabular}

